\title{
The Impact of the Free School Program and the Involvement of Parents in School Progress
}

\author{
Rifa' $i^{1 *)}$, Edi Harapan ${ }^{2}$, Tahrun $^{2}$ \\ ${ }^{1}$ SD Negeri Air Putih Ilir, South of Sumatra, Indonesia \\ ${ }^{2}$ Universitas PGRI Palembang, Indonesia \\ *Corresponding author. Email: rifaisarmadi@gmail.com
}

\begin{abstract}
The objectives of this research would be to assess and examine the effects of the Free School Program, Student Guardian Involvement in the Success of SD Negeri in the Plakat Tinggi District. This type of study is quantifiable descriptive. The sample in the experiment comprises of 51 respondents with data collection techniques in the form of a survey (questionnaire). The findings show that: 1) there is a positive effect of the Free School Program on School Progress; 2) there is a serious influence of Guardian Student Participation on School Progress; 3) there is a big impact between the Free School Program and the Participation of Guardian Students in School Progress.
\end{abstract}

Keywords: Free School Program, The Participation of Guardians, The Progress of the School

\section{INTRODUCTION}

The issue of the cost of education for each student tutor in the Musi Banyuasin Regency and, in particular, the guardians of SD Negeri students in the Plakat Tinggi District, as the subject of the research site, is that there is a doubt that the free education program is just a promise of a government campaign, the most obvious cause of which is the insecurity of this free education. In the case of new student admissions that have become a social media spotlight on admission fees that are perceived to be non-transparent and as if this levy is a one-sided decision without the consent of the school board such that it becomes a polemic in the city and dramatically decreases the spirit of educational affordability for all echoed people.

According to Aditya, et al [1] the topic of education levies can be positively linked by paying attention to the key aspects by empowering the transparency of levies, which is the main context for challenging education fees in compliance with the government's instructions. This case of levies will be determined. The Board members' response is very worried about the occurrence of levies and, because the distribution of costs related to school buildings is a breach of the rules, the clarity of the amount and benefits of levies must have a responsible place if they are used for uniform purposes outside school entrance fees, they should be obtained on the condition that they are addressed.
Law No. 20 of 2003 [2] on the implementation of education is obligated to follow a number of principles, namely that education is carried out in a democratic and just manner and is not discriminatory by respecting human rights, religious values, cultural values and national pluralism with a single institutional unity in a transparent and multi-meaning framework. All educational institutions in Indonesia have a duty and an obligation to create a generation that is capable and capable of competing on the world market [3]. In addition, implementation must also be part of a lifelong process of cultivating and motivating students through modelling, building up and improving student imagination in the learning process through the creation of a culture of reading, writing and arithmetic for all members of society, empowering all components of society through involvement in the implementation and control of quality Free school policy has positive and negative effects on the achievement of national priorities. A decision or a strategy is born out of a long and careful thinking. The same is true of the free school scheme. This event sounds very ordinary, but in fact it's a major event that we need to research and learn about together. Where these events will have an impact on the back and forth of a nation. Since the free school program will produce quality heirs to the nation who are both quality and decayed. Quality human capital can be realized through a successful educational mechanism and through quality educational institutions [4];[5]. 
The advent of a free school did not fix the issue, but instead created a more severe problem. Free schools are challenging the life of costly private schools because they have to pay their own expenses. The existence of free schools can be counterproductive to private schools, as parents are more interested in sending their children to free public schools. The second issue concerns consistency problems. The standard of free schools is frequently called into question by the group. The shortage of funding provided by the government is the reason why it is difficult for schools to provide quality education at minimal cost.

Free education based on a variety of sources and the outcomes of research and experience of developed and developing countries in the introduction of free education. Wikipedia, a free website, discusses free education as a free education for students. However, students will also have to pay for free education, such as books and other instructional materials. Free education can also be offered to students in the form of scholarships or grants that cover all or nearly all school costs. The Government and Local Governments are obliged to fund basic education, and the Government and local governments are obliged to ensure that compulsory education is carried out free of charge at least at the level of basic education. (UUD 1945 Article 31 Paragraph 2, National Education System Statute Article 11 Paragraph 2, Article 34 Paragraph 2 and Article 46 Paragraph 1 thereof. This ensures that basic education is free for all people of Indonesia. As Kristiawan et al [6] said, the creation of student character values, digital learning facilities and infrastructure, effective curricula and education policies are some of the solutions that need to be addressed in the world of education in order to optimize students' skills, human resource preparation, the development of student character, the development of digital learning facilities and infrastructure.

Previous research by Fransiska, et al [7] has shown that the performance of the teacher would be strong if the leadership style of the principal is successful and if the teacher also has a high work discipline. Teacher success can be optimized with the Principal's style of leadership that can motivate teachers to provide high school discipline so that they can always display their best performance in achieving school goals. The results of this study therefore support the view that the relationship between the innovative leadership of SD director Negeri Rambang Kapak Tengah and the teaching work discipline has a positive direct impact on the output of teachers.

The negative implications of this policy include: 1) with the free education program, parents who are only average people will believe that they only need to send their children to elementary or junior high school, 2) free school fees are only administrative expenses, creating opportunities for violence by reckless school parties, for example, whether or not they are studios. Performance is how to make the target more successful with a method that is "cheaper" It would be much easier to consider achieving positive outcomes in the education process without forgetting the good process. With the presence of this free school, we hope that it will be able to solve many problems of teaching efficiency in Indonesia, including the high cost of education, the time spent in the education process and the quality of teachers that are causing the inefficiency of the education process in Indonesia. Which is also very influential in developing Indonesia's human capital. Since last year, it has been introduced with the presence of a fee waiver at elementary and junior high school levels. However, students pay heed to other needs, such as textbooks, stationery, uniforms and so on.

Previous research by Utami et al [8] in the sense of the management function, work arrangements are institutional factors consisting of the formation of the organizational chain of command, the division of labor and the determination of authority. Good work structures would ensure the effective use of human capital. With this understanding, it can be clarified that work performed collectively, or work done in a structured manner, is the essence of a management purpose. The company shall pool its resources to achieve the desired results.

On the basis of this definition, it can be seen that the family is the smallest social unit consisting only of father, mother and child. The family offers the best education, that is, education that involves the growth of children's potential, namely: physical potential, thinking potential, and consciousness/heart potential. In the meantime, there can be a synergy of learning when there is a strong relationship between schools, teachers, adolescents, parents and the community.

Wildensyah [9] argues that the family is the first social institution known to children, and that, as an informal institution for educating children, the family has a duty to enforce it, and that its implementation lies with the parents, but many parents have not completely realized it. In addition, Mulyasa's parents are still concerned with different kinds of work and consider learning achievement to rely on schools and teachers [10].

According to Robbins [11], the improvement of public elementary schools is a condition for basic education institutions that are undergoing greater improvements than in the previous situation, and this progress can involve two aspects: physical and nonphysical progress, physical progress, e.g. the state of the school building that is becoming better structured, more full schools, improved hygiene, etc. In the meantime, non-physical improvement can be made in terms of enhancing the standard of schools, with metrics, better 
graduates than before, better qualifications of teaching staff, better school management than before, student achievement in some areas of substantial development in schools and outside of school, as presented.

The researcher is interested in taking the title: Impact of Free School Programs and Student Guardian Engagement in the Success of Public Elementary Schools in the Plakat Tinggi District.

\section{METHODS}

Methodology is a deciding factor in the merits of the writing of scientific papers [12]. According to Sukmadinata [13], the research method is a series of techniques or practices for conducting research based on basic assumptions, philosophic and ideological beliefs, questions and issues at hand. The research approach has a particular design for research. This research approach is quantitative research by explaining the results of the research.

Quantitative analysis is based on the theory of positivism, which emphasizes empirical phenomena and is quantitatively studied. The sample in this study is SD Negeri in the Jejawi District, with sampling in this study using objective sampling, that is to say, teachers who are used as test samples are teachers in of primary school with a total of 100 teachers. Techniques are required for the collection of data, both techniques for the provision of data and techniques for the classification of data that have been collected. The same argument has also been made by Sugiyono (2015) that the data collection approach is the method used to collect data, while the data collection methodology is the method used to carry out the method chosen to use questionnaire data and documentation. The data analysis method used in this study clear correlation and multiple regression data analysis techniques with the aid of the SPSS For Windows Version 22 software. The implementation process of the research included: (1) a descriptive analysis, (2) a test of the analysis criteria and (3) a test of the hypothesis.

\section{RESULTS AND DISCUSSION}

After testing the data analysis criteria, namely the normality test and the homogeneity test, the hypothesis test was continued. After the data are declared to have met the criteria to be checked, the hypothesis is tested using the t-test and the F-test to assess the effect on the variables to be tested in part and at the same time.

Table 1. Effects of Multiple Association Statistic Study and Coefficient of Determination

\begin{tabular}{|c|c|c|c|c|}
\hline \multicolumn{5}{|c|}{ Model Summary ${ }^{b}$} \\
\hline Model & $\mathrm{R}$ & $\begin{array}{c}\mathrm{R} \\
\text { Square }\end{array}$ & $\begin{array}{l}\text { Adjusted R } \\
\text { Square }\end{array}$ & $\begin{array}{l}\text { Std. Error of the } \\
\text { Estimate }\end{array}$ \\
\hline 1 & $.752^{\mathrm{a}}$ & .565 & .547 & 7.969 \\
\hline \multicolumn{5}{|c|}{$\begin{array}{l}\text { a. Predictors: (Constant), Guardian Participation }\left(X_{2}\right) \text {, Free School } \\
\text { Program }\left(X_{1}\right)\end{array}$} \\
\hline \multicolumn{5}{|c|}{ b. Dependent Variable: School Progress (Y) } \\
\hline
\end{tabular}

Table 2. Results of the F Test Analysis

\begin{tabular}{|c|c|c|c|c|c|c|}
\hline \multicolumn{7}{|c|}{ ANOVA $^{b}$} \\
\hline \multicolumn{2}{|c|}{ Model } & $\begin{array}{l}\text { Sum of } \\
\text { Squares }\end{array}$ & $\mathrm{df}$ & $\begin{array}{l}\text { Mean } \\
\text { Square }\end{array}$ & $\mathrm{F}$ & Sig. \\
\hline \multirow[t]{3}{*}{1} & Regression & 4040.850 & 2 & 2020.425 & 31.812 & $.000^{\mathrm{a}}$ \\
\hline & Residual & 3112.073 & 49 & 63.512 & & \\
\hline & Total & 7152.923 & 51 & & & \\
\hline \multicolumn{7}{|c|}{$\begin{array}{l}\text { a. Predictors: (Constant), Guardian Participation }\left(\mathrm{X}_{2}\right) \text {, Free School } \\
\text { Program }\left(\mathrm{X}_{1}\right)\end{array}$} \\
\hline \multicolumn{7}{|c|}{ b. Dependent Variable: School Progress (Y) } \\
\hline
\end{tabular}


Table 3. Results of $t$ test analysis

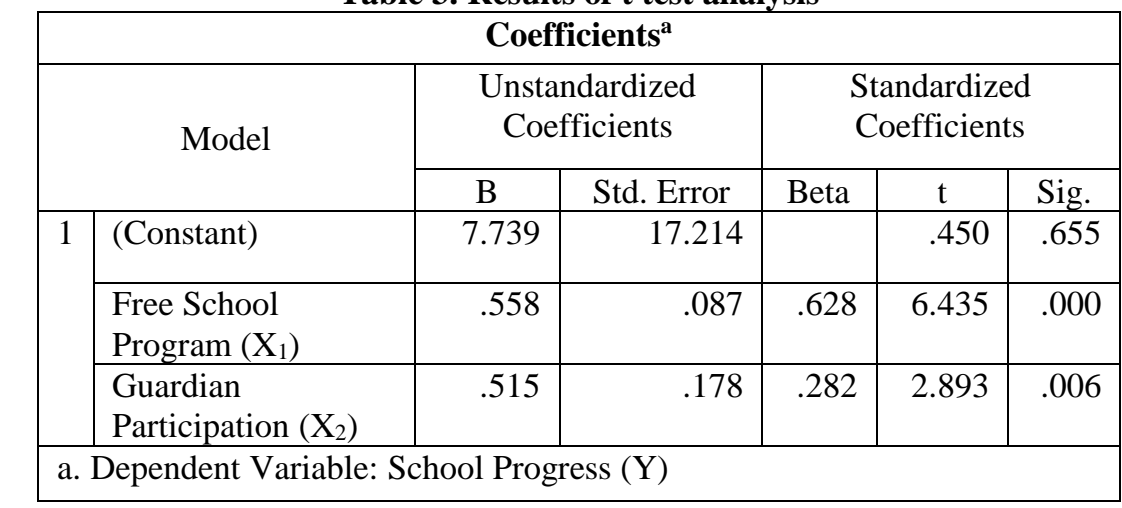

Source: Processed Results of the SPSS Program version 22 of 2020

Based on the results of the review of the research data using version 22 of the SPSS program. Before the study was carried out, the data criteria were first tested, namely the validity test and the reliability test. The data validity test was carried out using the validation test carried out with the validator, namely the PGRI Palembang University lecturer. Then proceed to verify the validity of the analysis using the SPSS software version 22 estimate. The results of the study validity measurement for the free school program variables remember that they are all correct so that the statement items can be further checked. The results of the estimation of the validation study for the participation variable of the guardians of the pupils are considered to be correct in order to further verify the things of the declaration. The results of the study validity measurement for the school progress variable note that all of them are correct so that the statement items can be further checked. The pre-requisite data test was then continued for the reliability test. After measurement using the SPSS version 22 program, it is known that the free school program variable has a value greater than the $\mathrm{r}$ table, that the student tutor participation variable is greater than the $\mathrm{r}$ table, and that the primary school advancement variable has a value greater than the $r$ table, so that it can be concluded that all the study variables are declared accurate.

\section{CONCLUSION}

Based on the findings of the research that has been conducted, it can be inferred that the free school policy has an effect on school success based on the results of the t-test study. This shows that the free school policy has had an impact on the success of SD Negeri in the district of Plakat Tinggi, which has replied to the first hypothesis. Parent engagement has an effect on school success based on the findings of the t-test study. This indicates that there is an impact of the presence of guardians on the success of SD Negeri in the district of Plakat Tinggi, according to the second hypothesis. The Free School Program and the Involvement of Guardian Students have a shared effect on School Success based on the findings of the $\mathrm{F}$ test third hypothesis.

\section{AUTHORS' CONTRIBUTION}

Rifa'i: designed and performed experiments and analysed data. Edi Harapan and Tahrun: proofing.

\section{ACKNOWLEDGMENTS}

Thank you to your family and colleagues, the Chancellor of the PGRI Palembang University, the Director of the PGRI Palembang University Postgraduate Program, the Chair of the PGRI Palembang University Education Management Masters Program and the supervisors who have contributed to the completion of this study journal. Then thank you, too, to the friends of PGRI Palembang University Postgraduate students and all those who helped to write and publish this journal.

\section{REFERENCES}

[1] Aditya. Y, Idris. A \& Anwar (2019). Peran Dinas Pendidikan Dalam Program Penyelenggaraan Pendidikan Gratis di Sekolah Dasar Negeri 016 Kota Samarinda [The Role of the Education Office in the Free Education Implementation Program at 016 Public Elementary Schools in Samarinda City]. eJournal Ilmu Pemerintahan, vol 7 (1): 507-518.

[2] Depdiknas. (2003). Undang-undang RI No.20 tahun 2003. tentang sistem pendidikan nasional [Republic of Indonesia Law No. 20 of 2003 on the national education system].

[3] Tobari., Kristiawan, M. \& Asvio, N. (2018). The Strategy of Headmaster on Upgrading Educational Quality in Asean Economic Community (AEC) Era. International Journal of Scientific \& Technology Research 7 (4).

[4] Rahmadoni, J. (2018). Isu Global Manajemen Pembiayaan Pendidikan di SD Indonesian Creative School Pekanbaru [Global Issues of Education Financing Management at SD Indonesian Creative School Pekanbaru]. Jurnal Manajemen, 
Kepemimpinan dan Supervisi Pendidikan 3(2), Juli-Desember.

[5] Asvio, N., Yamin, M., \& Risnita. (2019). Influence of Leadership Style, Emotional Intelligence and Job Satisfaction toward Organizational Commitment (Survey at SMA Muhammadiyah South Sumatera). International Journal of Scientific \& Technology Research 8 (8).

[6] Kristiawan, M., Nizarani., \& Syamsidar. (2019). Role of School on Forming Character of ZGeneration Through Entrepreneurial Skills. International Journal of Scientific \& Technology Research, 8(10).

[7] Fransiska. W., Harapan, E., \& Tahrun (2020). Pengaruh Kepemimpinan Visioner Kepala Sekolah dan Disiplin Guru terhadap Kinerja Guru Sekolah Dasar [The Effect of Principal Visionary Leadership and Teacher Discipline on Primary School Teacher Performance]. Journal of Education Research, 1(3), 2020, Pages 308-316.

[8] Utami. R., Ahmad. S., \& Eddy. S (2020). Implementasi Manajemen Sumber Daya Manusia [Implementation of Human Resource Management]. Journal of Education Research, 1(3), 2020, Pages 226-236.

[9] Wildensyah, I. (2015). Tahapan Pendidikan Anak dalam Islam yang Penting Diketahui oleh Orangtua dan Guru [Stages of Child Education in Islam that are Important for Parents and Teachers to Know] diakses dari situs Abiummi.com

[10] Mulyasa. (2013). Pengembangan dan Implentasi Pemikiran Kurikulum [Development and Implementation of Curriculum Thinking]. Bandung: Rosdakarya.

[11] Robbins. (2010). Efektivitas Organisasi Seri Manajemen [Organizational Effectiveness Management Series]. Jakarta: Erlangga.

[12] Muttaqin, K., \& Rahmadoni, J. (2020). Analysis and Design of File Security System AES (Advanced Encryption Standard) Cryptography Based. Journal of Applied Engineering and Technological Science (JAETS), 1(2), 113-123. https://doi.org/10.37385/jaets.v1i2.78

[13] Sukmadinata, N. S. (2015). Metode Penelitian Pendidikan [Educational Research Methods]. Bandung: Remaja Rosdakarya 